\title{
Autonomy for Universities Excellence - Challenges and Opportunities
}

\author{
P. S. Aithal ${ }^{1}$ \& Shubhrajyotsna Aithal ${ }^{2}$ \\ ${ }^{1}$ College of Management \& Commerce, Srinivas University, Mangalore - 575 001, INDIA \\ ${ }^{2}$ Faculty, College of Engineering \& Technology, Srinivas University, Mangalore, India \\ E-mail:psaithal@gmail.com
}

Type of the Paper: Review Paper.

Type of Review: Peer Reviewed.

Indexed In: OpenAIRE.

DOI: http://doi.org/10.5281/

Google Scholar Citation: IJAEML

\section{How to Cite this Paper:}

Aithal, P. S. \& Aithal, Shubhrajyotsna (2019). Autonomy for Universities ExcellenceChallenges and Opportunities. International Journal of Applied Engineering and Management Letters (IJAEML), 3(2), 36-52.

DOI: http://doi.org/10.5281/

International Journal of Applied Engineering and Management Letters (IJAEML) A Refereed International Journal of Srinivas University, India.

IFSIJ Journal Impact Factor for 2019-20 = 4.252

(C) With Authors.

\section{(c) (1) (9)}

This work is licensed under a Creative Commons Attribution-Non Commercial 4.0 International License subject to proper citation to the publication source of the work.

Disclaimer: The scholarly papers as reviewed and published by the Srinivas Publications (S.P.), India are the views and opinions of their respective authors and are not the views or opinions of the S.P. The S.P. disclaims of any harm or loss caused due to the published content to any party. 


\title{
Autonomy for Universities Excellence - Challenges and Opportunities
}

\author{
P. S. Aithal ${ }^{1}$ \& Shubhrajyotsna Aithal $^{2}$ \\ ${ }^{1}$ College of Management \& Commerce, Srinivas University, Mangalore - 575 001, INDIA \\ ${ }^{2}$ Faculty, College of Engineering \& Technology, Srinivas University, Mangalore, India \\ E-mail: psaithal@gmail.com
}

\begin{abstract}
The campus based universities offering higher education with the autonomy to innovate have opportunities to further improve the quality of their services and hence to reach excellence globally. Due to enhanced competitions through online courses, many campus based universities are redefining their strategies for either survival, or sustainability, or differentiation, or monopoly, or growth \& prosper depending on their present status and future plan. In this paper, we have analyzed the challenges and opportunities of present generation campus based universities and how such challenges can be addressed using their operational autonomy to aim for excellence. This includes the generic strategies to be used by campus based universities and their relevancy in the higher education system. Based on a review of private university performance \& ranking among US universities, it is argued that the private universities have better opportunity to innovate and hence to reach excellence. The nature and usage of autonomy by universities for academic, research, and technology based innovations, and autonomy for collaboration and expansion of campus based universities are discussed in terms of autonomy for stakeholders. Finally, the predicted consequences of the usage of autonomy by public and private universities are discussed.
\end{abstract}

Keywords: Autonomy in higher education, Excellence in higher education, Challenges in campus based universities, Consequences of autonomy.

\section{INTRODUCTION :}

Higher education is now considered as one of the service industries and hence focuses on providing quality service to its customers. Since quality is a dynamic quantity, one of the pre-requirement for providing quality service by organizations is autonomy for innovation. The universities offering higher education that have autonomy in their operations have opportunities to further improve the quality of their services and hence to reach excellence globally. Due to enhanced challenges through online courses of online universities, many existing campus based universities are redefining their services using either survival strategy, or sustainability strategy, or differentiation strategy, or monopoly strategy, or growth \& prosper strategy depending on their present status and future plans.

In many developed countries, the government gives more autonomy to universities and higher education institutions. Less political and bureaucratic control on higher education systems promote more autonomy to the universities to make innovations and hence to contribute to society. Higher education institutions if gets autonomy can think independently with responsibility and showing accountability. As a result, they contribute to the all-round development of higher education teachinglearning and research quality. Thus higher education institutions which can think independently with responsibility and accountability are considered as "thinking from the top". On the other hand, in many countries, higher education systems are controlled by corrupted politicians and bureaucrats and hence they cannot think independently to do innovations and forced to follow the regulations proposed by such accreditation organizations. Thus higher education institutions which cannot think independently with responsibility and accountability to do innovations are considered as 'thinking from the bottom". The HEIs which can think from the top can continue innovations in both academics 
and research. The HEIs which can only think from the bottom simply follow the regulations of accreditation organizations which are majorly controlled by corrupted politicians and bureaucrats.

As the technology is seen as a major affecting factor for innovations in higher education, adopting it in every phase to increase the quality and decrease the cost. Since technology is also used for offering ubiquitous education globally by any single organization, a threat is seen on campus based educational institutions. The ability of digital technology in providing online education service ubiquitously, the campus based education institutions, especially in higher education space, are facing challenges of existing. One of the constraints of online ubiquitous mass education is its inability of customization. This weakness along with the principles of industry 4.0 can be used by campus based higher education institutions for their sustainability by adopting customization model of education training. In higher education customization model, by adding research components, it can be seen that the students are working on different research problems so that both customization and differentiation in education model compared to online mass education can be achieved. Thus by adopting the customized education model [1], [2], [3], campus based education institutions can survive, sustain, differentiate, become a monopoly, and/or grow \& prosper.

Using students and faculty members for research based customization has dual advantages for campus based HEIs which include customization in education service offer and generation of intellectual property for the organization. Through customization of higher education to individual students, students can be differentiated each other in a single class which contributes heavily on the quality of education and involving students in the research and publications which in turn improves the quality further. Thus following research based higher education model is an innovation and the optimum solution for campus based HEIs from the threat of mass online open education model.

Higher education institutions follow various strategies for initiation by getting permission, sustain through expansion, differentiation through innovations, creating new space using autonomy to become a monopoly, and growth \& prosperity through collaboration. These strategies are called generic strategies and named as survival or black ocean strategy [4], sustainable or green ocean strategy [5], differentiation or red ocean strategy [6], monopoly or blue ocean strategy [7], and growth \& prosper or white ocean strategy [8].

Table 1 : Generic strategies in HEIs

\begin{tabular}{|l|l|l|l|l|l|}
\hline $\begin{array}{l}\text { S.N } \\
\text { o. }\end{array}$ & Problem & Type of problem & $\begin{array}{l}\text { Generic } \\
\text { Strategy used }\end{array}$ & $\begin{array}{l}\text { Strategic } \\
\text { Model }\end{array}$ & $\begin{array}{l}\text { Inventor/ } \\
\text { Reference }\end{array}$ \\
\hline 1 & Initiation & $\begin{array}{l}\text { External Challenges } \\
\text { to get permission, } \\
\text { renewal, etc. }\end{array}$ & Survival & $\begin{array}{l}\text { Black Ocean } \\
\text { strategy }\end{array}$ & $\begin{array}{l}\text { Aithal, P. S. } \\
\text { (2015). [4] }\end{array}$ \\
\hline 2 & $\begin{array}{l}\text { Expansion to } \\
\text { many courses }\end{array}$ & Internal challenge & Sustainability & $\begin{array}{l}\text { Green Ocean } \\
\text { strategy }\end{array}$ & $\begin{array}{l}\text { Hou, Shengtian } \\
\text { (2007). [5] }\end{array}$ \\
\hline 3 & $\begin{array}{l}\text { Innovations } \\
\text { Internal challenge to } \\
\text { face } \text { Differentiation } \\
\text { competitions }\end{array}$ & $\begin{array}{l}\text { Red Ocean } \\
\text { strategy }\end{array}$ & $\begin{array}{l}\text { Porter, M. E. } \\
\text { (1997). [6] }\end{array}$ \\
\hline 4 & $\begin{array}{l}\text { Creating new } \\
\text { space using } \\
\text { autonomy }\end{array}$ & $\begin{array}{l}\text { Internal challenge to } \\
\text { become unique }\end{array}$ & Monopoly & $\begin{array}{l}\text { Blue Ocean } \\
\text { strategy }\end{array}$ & $\begin{array}{l}\text { Kim, W. C. Et al } \\
\text { (2005). [7] }\end{array}$ \\
\hline 5 & $\begin{array}{l}\text { Collaboration } \\
\text { External challenge to } \\
\text { grow globally }\end{array}$ & $\begin{array}{l}\text { Growth \& } \\
\text { prospering }\end{array}$ & $\begin{array}{l}\text { White Ocean } \\
\text { strategy }\end{array}$ & $\begin{array}{l}\text { Aithal, P. S. } \\
\text { (2016). [8] }\end{array}$ \\
\hline
\end{tabular}

Table 2 : Relevancy of Generic strategies in HEIs

\begin{tabular}{|l|l|l|l|}
\hline S.No & $\begin{array}{l}\text { Generic } \\
\text { Strategies used } \\
\text { in HEIs }\end{array}$ & Purpose & Description \\
\hline 1 & $\begin{array}{l}\text { Black ocean } \\
\text { strategy }\end{array}$ & Survival & $\begin{array}{l}\text { Survival from a catastrophic problem so that } \\
\text { it can continue in the business instead of } \\
\text { closing down }\end{array}$ \\
\hline
\end{tabular}




\begin{tabular}{|l|lr|l|l|}
\hline 2 & $\begin{array}{l}\text { Green } \\
\text { strategy }\end{array}$ & Ocean & Sustainability & $\begin{array}{l}\text { Long time sustainability so that the } \\
\text { organization can continue in its business }\end{array}$ \\
\hline 3 & $\begin{array}{l}\text { Red } \\
\text { strategy }\end{array}$ & Ocean & Differentiation & $\begin{array}{l}\text { To face the competition of other firms from } \\
\text { the same industry }\end{array}$ \\
\hline 4 & $\begin{array}{l}\text { Blue } \\
\text { strategy }\end{array}$ & Ocean & Monopoly & $\begin{array}{l}\text { To create competition less environment on } \\
\text { their products or services }\end{array}$ \\
\hline 5 & $\begin{array}{l}\text { White } \\
\text { strategy }\end{array}$ & Ocean & Growth \& Prosper & To achieve the goal using a mixed strategy \\
\hline
\end{tabular}

\section{OBJECTIVES :}

The objective of this paper include :

(1) To develop a conceptual discussion based on trend analysis to identify the challenges of campus based universities to improve the quality of higher education at low cost by awaking the responsibilities of stakeholders along with imposing accountability.

(2) To study the nature and usage of autonomy given to higher education institutions for academic, research, and technology based innovations, and autonomy for collaboration and expansion.

(3) To discuss the challenges for campus based universities to attain excellence.

(4) To review autonomy based Private university performance \& Ranking

(5) To analyze the challenges of autonomy for the stakeholders.

(6) To mention the predicted Consequences of Autonomy for Universities.

\section{RELATED WORK :}

There are many research work and scholarly publications on the area of quality in higher education with a focus of Autonomy for excellence. Table 3 depicts such scholarly papers on the field with the corresponding reference.

Table 3 : Some of the related scholarly work and publications during last few years.

\begin{tabular}{|c|c|c|c|}
\hline S.No. & Issues & Focus & Reference \\
\hline 1 & $\begin{array}{l}\text { Measurement of university } \\
\text { quality }\end{array}$ & Campus autonomy & $\begin{array}{l}\text { Volkwein, J. F. (1986). } \\
\text { [9] }\end{array}$ \\
\hline 2 & Quality in Higher Education & Total quality management & $\begin{array}{l}\text { McCulloch, M. (1993). } \\
\text { [10] }\end{array}$ \\
\hline 3 & Quality in Higher Education & $\begin{array}{l}\text { Towards a general model of } \\
\text { quality assessment }\end{array}$ & $\begin{array}{l}\text { Van Vught, F. A., et al. } \\
\text { (1994). [11] }\end{array}$ \\
\hline 4 & Survival through excellence & $\begin{array}{l}\begin{array}{l}\text { Prospects for the } \\
\text { university }\end{array} \\
\text { Polish } \\
\end{array}$ & $\begin{array}{ll}\text { Kwiatkowski, } & \text { S. } \\
\text { (1990). [12] } & \end{array}$ \\
\hline 5 & Quality in Higher Education & $\begin{array}{l}\text { Exploring the development of } \\
\text { quality }\end{array}$ & $\begin{array}{l}\text { Avdjieva, M., et al. } \\
\text { (2002). [13] }\end{array}$ \\
\hline 6 & $\begin{array}{l}\text { Management in Higher } \\
\text { Education }\end{array}$ & Quality or control? & $\begin{array}{l}\text { Milliken, J., et al. } \\
\text { (2004) [14] }\end{array}$ \\
\hline 7 & $\begin{array}{lrr}\text { Changing } & \text { the } & \text { policy } \\
\text { environment } & \text { in } & \text { Higher } \\
\text { Education } & & \\
\end{array}$ & $\begin{array}{lll}\text { Academic identity } & \text { and } \\
\text { autonomy } & \end{array}$ & $\begin{array}{l}\text { Henkel, M. (2005). } \\
\text { [15] }\end{array}$ \\
\hline 8 & Quality in Higher Education & $\begin{array}{l}\text { In pursuit of excellence and } \\
\text { equity }\end{array}$ & $\begin{array}{l}\text { Bridges, D. (2006). } \\
{[16]}\end{array}$ \\
\hline 9 & Quality in Higher Education & $\begin{array}{lcr}\begin{array}{l}\text { Institutional } \\
\text { increasing } \\
\text { outside actors }\end{array} & \text { dependency } & \text { with } \\
& \\
\end{array}$ & Bladh, A. (2007). [17] \\
\hline 10 & Quality in Higher Education & Education through research & $\begin{array}{l}\text { Simons, M., et al. } \\
\text { (2007). [18] }\end{array}$ \\
\hline 11 & Research in Higher Education & $\begin{array}{l}\text { Funding and autonomy for } \\
\text { reform and accountability }\end{array}$ & $\begin{array}{l}\text { Kallison, J. M., et al. } \\
\text { (2010). [19] }\end{array}$ \\
\hline
\end{tabular}




\begin{tabular}{|c|c|c|c|}
\hline 12 & Quality in Higher Education & $\begin{array}{l}\text { Excellence, quality and the } \\
\text { diversity of higher education } \\
\text { systems }\end{array}$ & Bleiklie, I. (2011). [20] \\
\hline 13 & $\begin{array}{l}\text { Developing excellence in } \\
\text { Universities }\end{array}$ & $\begin{array}{l}\text { Chinese university reform in } \\
\text { three steps - }\end{array}$ & Zhang, J. (2014). [21] \\
\hline 14 & $\begin{array}{l}\text { Shifting fundaments of } \\
\text { European higher education } \\
\text { governance }\end{array}$ & $\begin{array}{l}\text { Competition, ranking, autonomy } \\
\text { and accountability }\end{array}$ & $\begin{array}{l}\text { Erkkilä, T., (2014). } \\
\text { [22] }\end{array}$ \\
\hline 15 & $\begin{array}{l}\text { Integrity and quality in } \\
\text { universities }\end{array}$ & $\begin{array}{l}\text { Accountability, excellence and } \\
\text { success }\end{array}$ & O'Neill, O. (2015). [23] \\
\hline 16 & $\begin{array}{l}\text { Innovations in private } \\
\text { universities }\end{array}$ & A case of Srinivas university & $\begin{array}{l}\text { Aithal, P. S., (2016). } \\
\text { [24] }\end{array}$ \\
\hline 17 & Quality in Higher Education & $\begin{array}{l}\text { Autonomy for Excellence in } \\
\text { Higher Education in India }\end{array}$ & $\begin{array}{l}\text { Sankaran, K. (2016). } \\
\text { [25] }\end{array}$ \\
\hline 18 & Excellence in higher education & $\begin{array}{l}\text { Benchmarking towards } \\
\text { excellence in higher education. }\end{array}$ & $\begin{array}{ll}\text { Tasopoulou, } & \text { K., } \\
\text { (2017). [26] } & \\
\end{array}$ \\
\hline 19 & Excellence in higher education & $\begin{array}{l}\text { Excellence of universities versus } \\
\text { autonomy, funding and } \\
\text { accountability }\end{array}$ & $\begin{array}{l}\text { Michavila, F., et al. } \\
\text { (2018). [27] }\end{array}$ \\
\hline
\end{tabular}

\section{CHALLENGES FOR CAMPUS BASED UNIVERSITIES :}

Universities promoted by public and private sectors can enjoy considerably more autonomy compared to other higher education institutions affiliated to these universities. Hence the further discussions in this section are on such universities which can enjoy autonomy in the first place to the make right decisions at the right time. An autonomous higher education institution or a university faces many challenges while functioning and trying to fulfill its objectives in the society which are identified using a focus group method [28] and the major challenges based on various factors are shown in figure 1 and explained below :

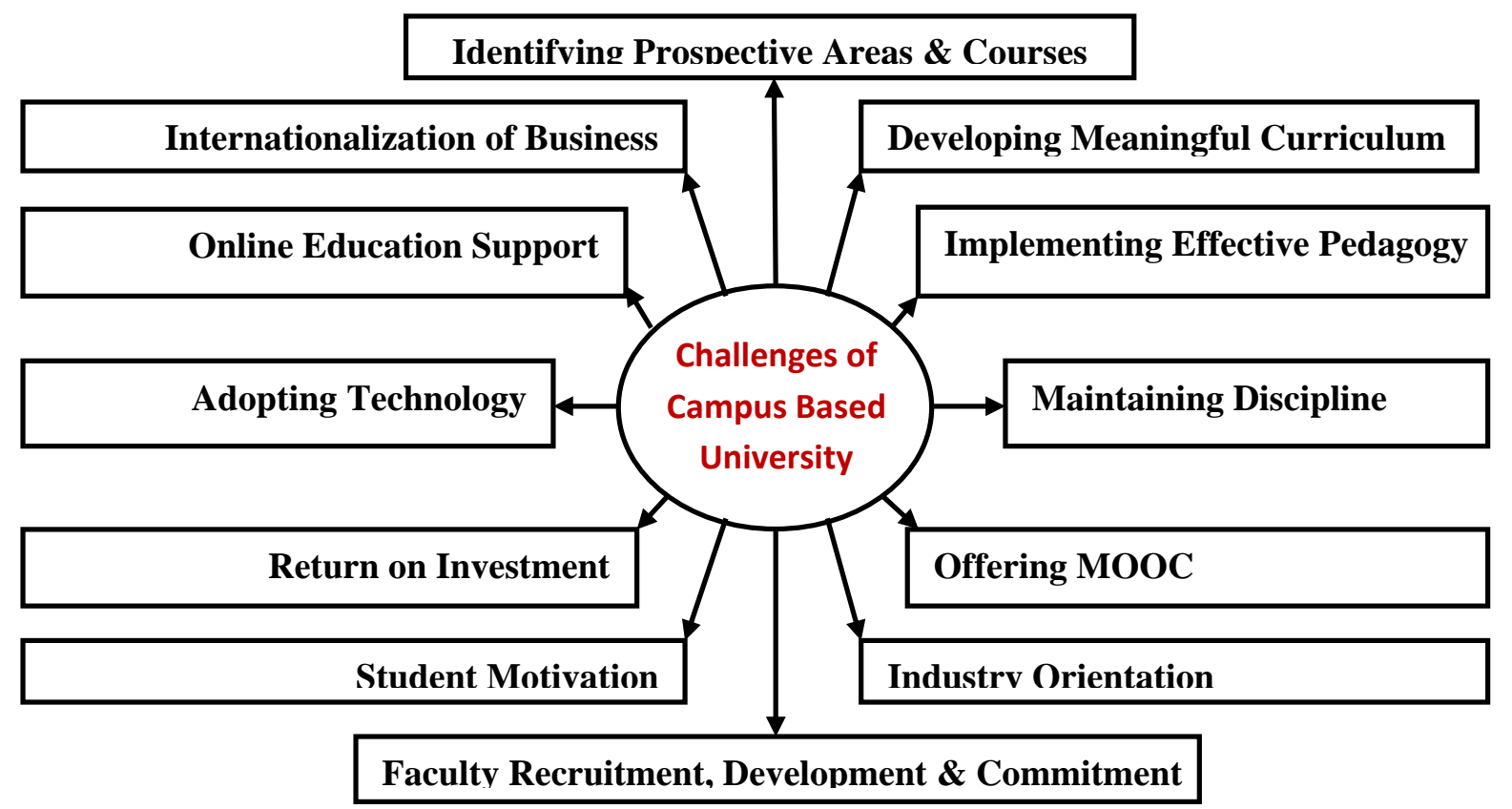

Fig. 1 : Block diagram of major Challenges of autonomous Campus-based Universities

(1) Challenges of Identifying Prospective Areas \& Courses :

University has to offer adequately divert courses in horizontal areas including in all possible professional areas both natural and philosophical sciences, both pure and applied areas, and in vertical 
areas like certificate, diploma, under-graduation, post-graduation, doctoral research and post-doctoral research degree courses. The horizontal areas and vertical courses to be offered in a Campus based University to cover many possible areas and courses of study are depicted in Table 4 . The university should accumulate the required resources for offering courses in such wide areas of interest. The resources include physical infrastructure, digital infrastructure, innovative academic infrastructure, intellectual infrastructure, emotional infrastructure, and network infrastructure in the adequate form [29] to provide justice to students and researchers. Depending on the resources availability, societal requirement, and leadership abilities, the university decides its priorities in identifying areas and courses to offer higher education services.

Table 4: Horizontal areas and Vertical courses to be offered in a Campus based University

\begin{tabular}{|c|c|c|c|c|}
\hline & Horiz & ntal Areas & & Vertical Courses \\
\hline Natural Sci & & Philoso & hical Sciences & Certificate \\
\hline Pure & Applied & Pure & Applied & Diploma \\
\hline Physical & Engineering, & Mathematics, & Computer & UG Degree \\
\hline sciences, & Medicine, & Arts, & programming, & PG Degree \\
\hline Chemical & Allied & Commerce, & Business & Doctoral Research Degrees \\
\hline $\begin{array}{l}\text { sciences, } \\
\text { Biological }\end{array}$ & $\begin{array}{l}\text { medicine, } \\
\text { All other }\end{array}$ & & $\begin{array}{l}\text { management, } \\
\text { Entrepreneurship }\end{array}$ & $\begin{array}{l}\text { Post Doctoral Research } \\
\text { Degrees }\end{array}$ \\
\hline sciences & $\begin{array}{l}\text { applied science } \\
\text { areas }\end{array}$ & & etc. & Honorary Degrees \\
\hline
\end{tabular}

\section{(2) Challenges of Developing Meaningful Curriculum :}

Once the areas and courses are identified, the university should focus on developing meaningful curriculum for these courses based on the objective of imparting knowledge, skills, and experience by providing information on past developments, present uses, and future changes in the subjects. Identifying and accumulating such information to develop optimum curriculum need many resources including books, internet resources, industrial experts, and research articles as shown in schematic figure 2 .

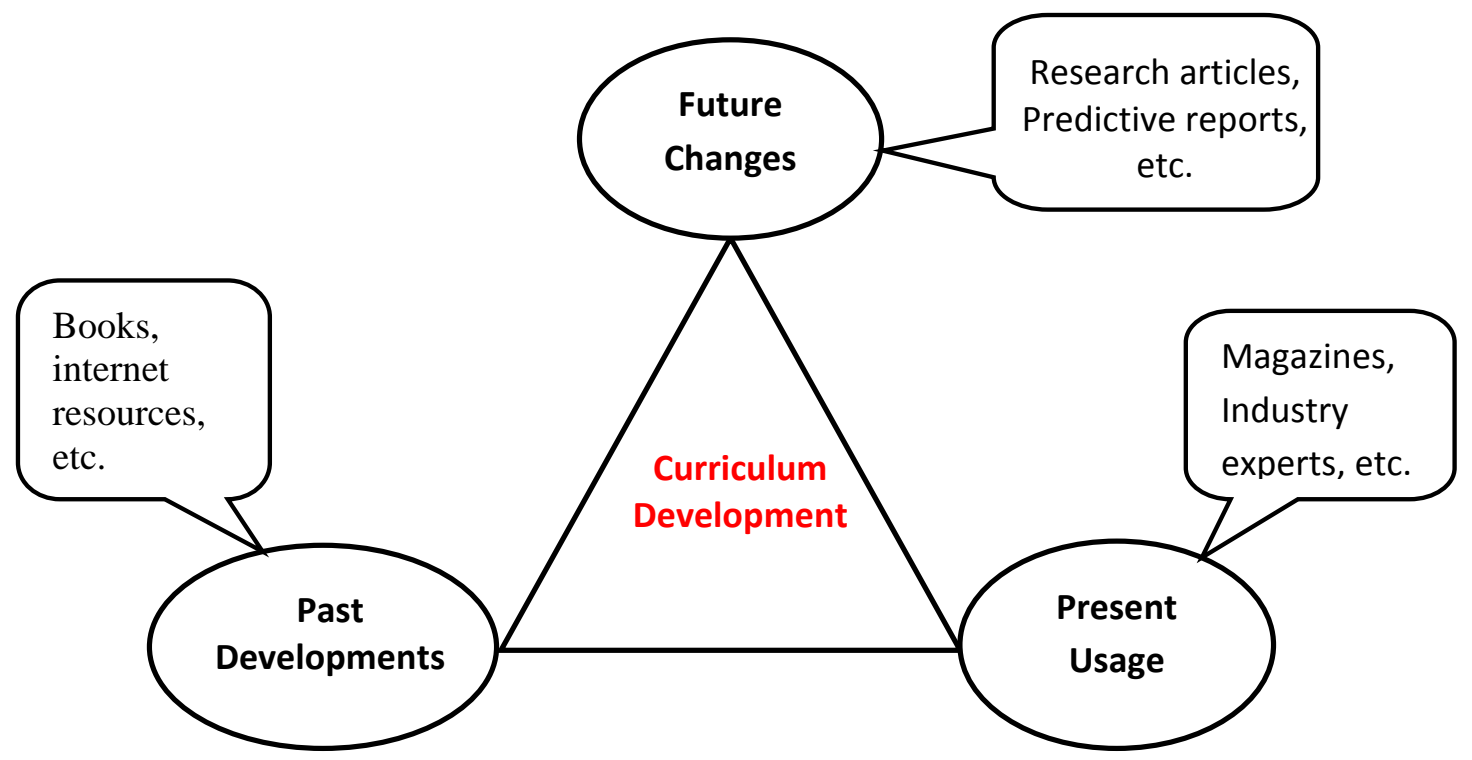

Fig. 2 : Factors effecting curriculum development and resources to be used

The challenges include how effective the curriculum to address the new problems in the field to solve them optimally to improve the quality of products and services. The three main factors which effect the meaning curriculum development are (1) Past developments in the field/subject, (2) Current usage of the field/subject in society, and (3) Future expected changes in the field/subject as per industry/society requirement. While designing a curriculum for academic learning, it is expected that 
about $50 \%$ of the curriculum should be focussed on past developments and such information mainly available from textbooks and various internet sources. At least $25 \%$ of the curriculum should be focussed on current usage of subject and its applications in industry \& society and such information is available from various magazines, industry experts, online resources, etc. Remaining $25 \%$ of the curriculum should be focussed on future changes expected based on past and present usage and the ability of the subject to solve problems and aspirations in society and such information can be generated by research and referring various research articles, predictive reports, etc. The curriculum developed for any subject based on above format becomes meaningful curriculum from student development point of view.

\section{(3) Challenges of Implementing Effective Pedagogy:}

After developing meaningful curriculum which shall focus on overall development of the students, the university should focus on effective implementation of it by identifying a proper and suitable pedagogy. Universities face many challenges of identifying suitable pedagogy and implementing them effectively. These challenges include developing an effective pedagogy, identifying and appointing suitable faculties as trainers, motivating and facilitating students in research to create new knowledge in the field, evaluating the competency of the students at the end of the training period, etc. The university should use its autonomy to develop a suitable and unique "student development model" to implement the pedagogy effectively. This will also enhance the employability and entrepreneurship ability of the graduates. Student integrated development model [30] may include enhanced credits per semester, STEAM (Science, Technology, Engineering, Arts \& design, and Mathematics) focus, Value added subjects called Employment Skill Enhancement Programs (ESEP) in every semester, Enhanced experimental learning (E.L.) part, Company \& Patent analysis, Intellectual property (I.P.) awareness workshop, Compulsory industry internship, and Compulsory intellectual property right (I.P.R.) registration by student in the form of either scholarly publication, copyright, or patent filing to get the graduation certificate. An example of student integrated development model published in reference [30] is reprinted in figure 3 with suitable modifications.

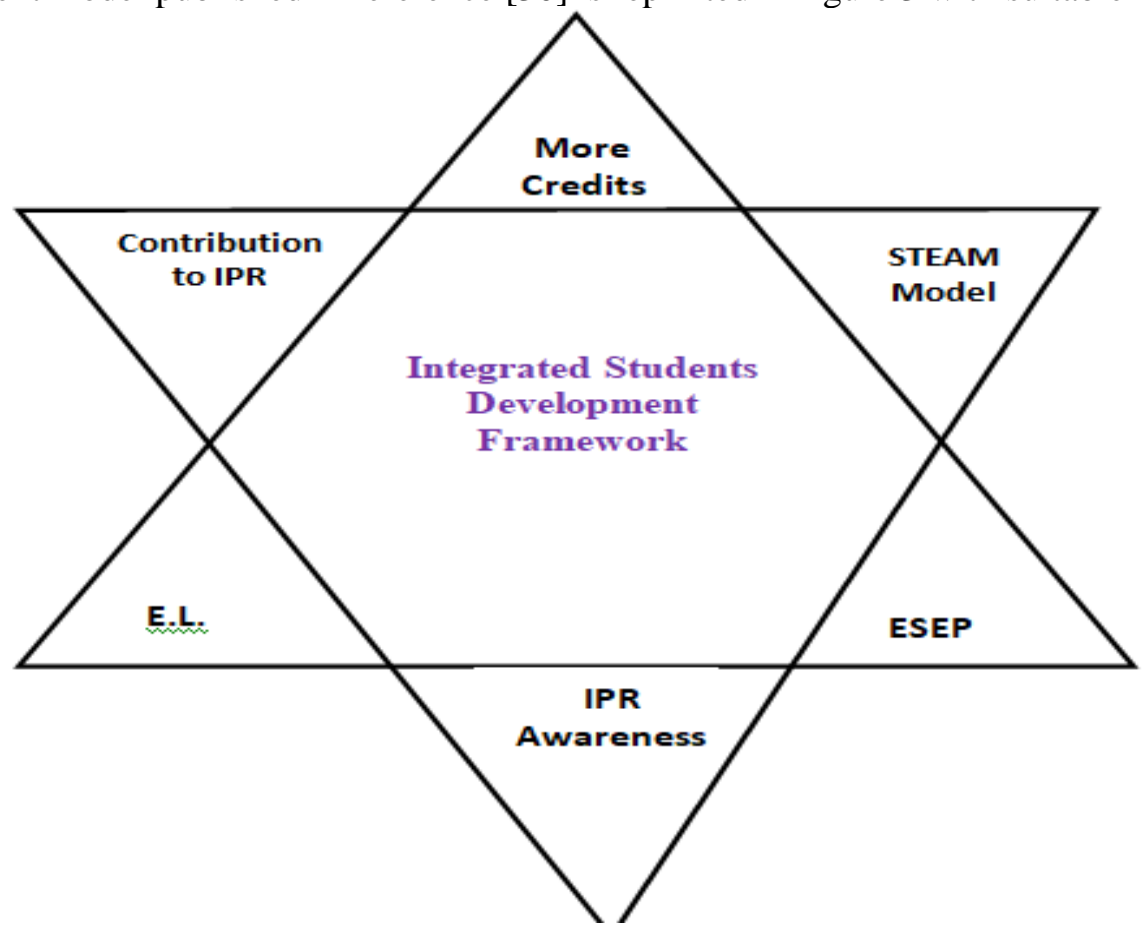

Fig. 3 : Integrated Student development Framework for effective implementation of pedagogy [30].

(4) Challenges of Maintaining Discipline :

Maintaining discipline in the campus to support calm and learning atmosphere is a challenge in many campus based universities. Attendance and classroom discipline can be controlled through strict rules 
and regulations but maintaining overall discipline in the campus including hostels need a strong and tuff leadership. These challenges are intense in public universities compared to private universities. This is due to the fact that public universities are controlled by politicians and if the student unions are having their roots with various anti-socials, maintaining discipline and ensuring justice to every stakeholder is very difficult. Maintaining discipline also include the justice to all students irrespective of their caste, religion, and gender. The discipline leads to core values to be inculcated in each stakeholder and adds name, fame and brand value to the university. Based on observations, private universities can maintain better discipline in the campus than public universities due to the fact that public universities in developing countries. Maintaining discipline is a challenge

\section{(5) Challenges of Adopting Technology:}

Use of technology in promotion of the university, admission to different courses, using suitable pedagogy, effective teaching \& learning process, evaluation system, and providing information to enhance knowledge, skills, and experience etc. are essential. Adopting latest technology gives many advantages to fulfill the objectives of the university to impart effective education to the students. Adopting suitable Technology also helps in effective collection of information for research and analysis. Identifying suitable technology for teaching, learning, administration, and research by providing office automation, learning management system, administrative automation, online digital library, online examination and evaluation system are essential. Challenges are due to identifying suitable technology and its adoption to optimize the performance of the universities at all levels. Since the technology useful for innovation and automation of higher education services is changing, universities face challenges in identifying and adopting a suitable technology, investment of resources for it, training the staff members, and maintaining adopted technology, updating it as per changes etc. Universities struggle to become technology leaders to differentiate them. Technology adoption can be broadly divided into two categories as (1) use of technology and (2) promotion of technology. Universities use available education technologies (ET) to automate their functions and teaching learning processes to become effective and efficient in offering higher education services. In addition, universities have responsibility in promoting technology by their active involvement in research and development. For this, universities follow two strategies as improving existing technologies and their applications in solving problems of the society, and involving in the research and development of new emerging technologies to identify new innovative opportunities to solve problems of the society. These problems may be basic problems of people needs, advanced problems of people wants, and to realize their dreamy desires. The challenges are mainly from accumulation of various resources to adopt and promote latest optimum technology for higher education services and research [31].

\section{(6) Challenges of Online Education support :}

Online education support for the students and faculty members of the campus based universities is present and future requirement. Both full-time and part-time students expect online e-services related to various information through university website, university app, university blogs, Course blogs, faculty blogs, student and parent based push and pull information services, academic information, teaching-learning resources including online library resources, online knowledge bases, online skill development services, online support for examination and evaluations, etc. and is posses technology challenges, pedagogy challenges, process challenges, customization challenges etc. Universities have to develop suitable model and follow-up to provide optimum online support to their promised services.

\section{(7) Challenges of Offering MOOC :}

Campus based universities if specialized in certain areas or subjects can offer Mass Online Open Courses (MOOC) globally using online education technology. This model gives the opportunity to become unique in such specialized areas and attract global students. Many universities across the world presently offer many level courses like certificate, diploma, undergraduate, postgraduate, and research courses under this model. Based on the subject and uniqueness of the course, the university can register a huge number of students and earn and contribute substantially to its revenue. The challenges in offering MOOC include choosing course subjects and level, promotion of the courses, 
adopting suitable technology and method, initial investment, choosing pedagogy, course delivery, online examination and evaluation, etc.

\section{(8) Challenges of Industry Orientation :}

Universities which offers varied courses can produce employable graduates only if they involve related industries while offering the courses including identifying the courses, developing the curriculum, choosing the pedagogy, teaching-learning process, and even in evaluation. The challenges include developing and offering super-specialty courses as per appropriate industry requirement, Collaborating with industry and industry experts as consultants, offering experimental learning opportunities during the course, offering compulsory industry internship during the course, etc. The universities which offer course autonomy to the course coordinators can handle such challenges in an efficient manner.

(9) Challenges of Faculty Recruitment, development, \& commitment :

Qualified and innovative faculty members are big resources of great university. Such faculty members not only create innovative academic infrastructure but also contribute heavily for intellectual property infrastructure of the university. Identifying and recruiting suitable faculty, motivating and maintaining their commitment in process of attaining excellence by the universities are important and is depends on their autonomy. Private universities, having more autonomy in faculty recruitment process are able to recruit comparatively more innovative faculty members if they want to do so [32]. Public sector universities having additional responsibilities on various reservations and hence may have to face constraints for recruiting innovative and committed faculty members. However, in both cases, target setting, continuous follow-up, and accountability are important for enhancing faculty performance.

\section{(10) Challenges of Student Motivation:}

One of the major challenges in higher education system is keeping students motivated so that they will show interest in higher education and research. The objective of higher education is confidence building along with knowledge, skills, and experience [33]. This also includes developing networks through fellow students, friends, learned faculties, and industry networks. The challenges include, developing and offering an attractive curriculum, pedagogy on experimental and interactive learning, stimulating innovative thinking ability through research etc. As discussed in earlier section, providing ambient learning infrastructures including physical, digital, innovative academic, intellectual, emotional, and networked with industry and alumni motivated the students to take part in higher education training activities and builds confidence along with knowledge, skills, and experience [34].

\section{(11) Challenges of Internationalization of Business :}

The objective of every business is enhancing long term profit. In higher education service also universities should either self-sustainable or dependant on public finance to balance their expenditure. Many universities are now trying to admit foreign students or collaborate with foreign universities to increase their revenue. There are many models for internationalization of higher education service by the universities which include, international admission, dual degree programs through mutual credit transfer, international internship, etc. Internationalization of university education posses many challenges which include discipline problem, language problem, cultural and traditional clash, infrastructural improvement, language problem, etc. Campus based universities which have autonomy and resources to offer education to global students are going to be sustainable in future arena.

\section{(12) Challenges of Return on Investment :}

Universities should be self sustainable unless they are continuously subsidized by the government for their functions. Return on investment of universities is a performance measure of universities to evaluate the efficiency of the University for its Self Sufficiency. Return on investment tries to measure the amount of return relative to the cost of investment. The universities can sustain for long period and grow and prosper if they operate with an environment with good return on investment.

\section{AUTONOMY AS AN OPPORTUNITY TO ATTAIN EXCELLENCE :}


Making independent and timely decisions using autonomy is the opportunity for many universities to attain excellence in higher education services. Both excellence in academics and excellence in research contributions are possible for the universities which use their autonomy for innovations effectively. As per many arguments, in higher education system, autonomy is not given but it has to be taken by the decision makers to take innovative and bold decisions to reach excellence in their services.

\subsection{Historical learning from autonomous USA Universities :}

How autonomy to Private Universities in USA allowed them to grow as Top universities is shown in Table 5. Table 5 list top 10 universities in USA for the year 2019 based on two ranking agencies : (1) www.topuniversities.com and (2) www.timeshighereducation.com. As per topuniversities.com ranking, all Top 10 universities in USA for the year 2019 are private universities and as per timeshighereducation.com ranking, out of top 10 USA universities, 9 of them are private universities which have used their autonomy for innovations to reach excellence. Private universities do innovations to excel in higher education related service offerings using their autonomy. Private universities in USA are the best examples and became world toppers and offering excellent higher education. These universities developed internal accountability for the faculty members for service quality.

Table 5 : How autonomy supported USA private universities to reach top ranking level

\begin{tabular}{|c|c|c|c|c|}
\hline $\begin{array}{l}\text { S. } \\
\text { No. }\end{array}$ & $\begin{array}{l}\text { Name of the US University and } \\
\text { State }\end{array}$ & Private / Public & $\begin{array}{l}\text { Top } \\
\text { Universities } \\
\text { Ranking }\end{array}$ & $\begin{array}{l}\text { Times Higher } \\
\text { education } \\
\text { Ranking }\end{array}$ \\
\hline 1 & $\begin{array}{l}\text { Stanford University } \\
\text { California }\end{array}$ & $\begin{array}{ll}\text { Private } & \text { Research } \\
\text { University } & \\
\end{array}$ & 2 & 1 \\
\hline 2 & $\begin{array}{lll}\text { Massachusetts } & \text { Institute } & \text { of } \\
\text { Technology } & & \\
\text { Massachusetts } & & \\
\end{array}$ & $\begin{array}{ll}\text { Private } & \text { Research } \\
\text { University } & \end{array}$ & 1 & 2 \\
\hline 3 & $\begin{array}{l}\text { California Institute of Technology } \\
\text { California }\end{array}$ & $\begin{array}{ll}\text { Private } & \text { Research } \\
\text { University } & \\
\end{array}$ & 4 & 3 \\
\hline 4 & $\begin{array}{l}\text { Harvard University } \\
\text { Massachusetts }\end{array}$ & $\begin{array}{ll}\text { Private } & \text { Research } \\
\text { University } & \\
\end{array}$ & 3 & 4 \\
\hline 5 & $\begin{array}{l}\text { Princeton University } \\
\text { New Jersey }\end{array}$ & $\begin{array}{ll}\text { Private } & \text { Research } \\
\text { University } & \end{array}$ & 6 & 5 \\
\hline 6 & $\begin{array}{l}\text { Yale University } \\
\text { Connecticut }\end{array}$ & $\begin{array}{ll}\text { Private } & \text { Research } \\
\text { University } & \end{array}$ & 8 & 6 \\
\hline 7 & $\begin{array}{l}\text { University of Chicago } \\
\text { Illinois }\end{array}$ & $\begin{array}{ll}\text { Private } & \text { Research } \\
\text { University } & \\
\end{array}$ & 5 & 7 \\
\hline 8 & $\begin{array}{l}\text { Johns Hopkins University } \\
\text { Maryland }\end{array}$ & $\begin{array}{ll}\text { Private } & \text { Research } \\
\text { University } & \\
\end{array}$ & 12 & 8 \\
\hline 9 & $\begin{array}{l}\text { University of Pennsylvania } \\
\text { Pennsylvania }\end{array}$ & $\begin{array}{ll}\text { Private } & \text { Research } \\
\text { University } & \\
\end{array}$ & 10 & 8 \\
\hline 10 & $\begin{array}{l}\text { University of California } \\
\text { California }\end{array}$ & $\begin{array}{ll}\text { Public } & \text { Research } \\
\text { University } & \\
\end{array}$ & 14 & 10 \\
\hline 11 & $\begin{array}{l}\text { Cornell University } \\
\text { New York }\end{array}$ & $\begin{array}{ll}\text { Private } & \text { Research } \\
\text { University } & \\
\end{array}$ & 7 & 14 \\
\hline 12 & $\begin{array}{l}\text { Columbia University } \\
\text { New York }\end{array}$ & $\begin{array}{ll}\text { Private } & \text { Research } \\
\text { University } & \\
\end{array}$ & 9 & 11 \\
\hline
\end{tabular}

\subsection{Autonomy proposal in National Education Policy Proposal :}

Recently, the Indian National Education Policy proposal 2019 has suggested for enhancing autonomy in higher education (table 6). It has suggested the affiliated HEIs to elevate themselves to autonomous degree granting institutions so that they can serve independently through their own 
governing councils. The Indian private universities which are more than $50 \%$ in number are also expected to get more autonomy and going to be free from all kind of governmental interventions including annual permission from regulatory/recognition bodies so that they can focus only on quality education and research through continuous innovations to reach excellence.

Table 6 : Autonomy components in Indian Higher Education as per National Education policy proposal 2019 [35]

\begin{tabular}{|c|c|c|c|}
\hline $\begin{array}{l}\text { S. } \\
\text { No. }\end{array}$ & $\begin{array}{l}\text { Autonomy } \\
\text { components }\end{array}$ & $\begin{array}{ll}\text { Public Universities/ Public } \\
\text { Autonomous Colleges }\end{array}$ & \begin{tabular}{lll} 
Private & \multicolumn{2}{c}{ Self-financing } \\
Universities & $/$ & Private \\
Autonomous Colleges & \\
\end{tabular} \\
\hline 1 & Starting new courses & Within six months & Immediate whenever required \\
\hline 2 & Admission & $\begin{array}{l}\text { Through national admission test } \\
\text { (NEA) ranking \& counselling as } \\
\text { per reservation policy of the } \\
\text { government }\end{array}$ & $\begin{array}{l}\text { Through institutional admission } \\
\text { test \& merit based admission. } \\
\text { Number of seats can be varied } \\
\text { depending on demand. }\end{array}$ \\
\hline 3 & Faculty appointment & $\begin{array}{l}\text { Through an independent } \\
\text { committee }\end{array}$ & $\begin{array}{l}\text { Through an independent } \\
\text { committee. The institution need } \\
\text { not follow reservations }\end{array}$ \\
\hline 4 & Financial autonomy & $\begin{array}{l}\text { Low. Financial decisions depends } \\
\text { on government policies }\end{array}$ & $\begin{array}{l}\text { High. Freedom on Decision on } \\
\text { investment for expansion and } \\
\text { growth }\end{array}$ \\
\hline 5 & Education model & Liberal education & Liberal education \\
\hline 6 & Internationalization & $\begin{array}{l}\text { Possible but slow due to low } \\
\text { accountability }\end{array}$ & $\begin{array}{l}\text { Possible and accelerated due to } \\
\text { pressure on innovativeness }\end{array}$ \\
\hline 7 & Regulatory bodies & $\begin{array}{l}\text { Only one regulating body instead } \\
\text { of many regulatory regime }\end{array}$ & $\begin{array}{l}\text { Only one regulating body instead } \\
\text { of many regulatory regime }\end{array}$ \\
\hline 8 & Research funding & \begin{tabular}{llr} 
Dependency & \multicolumn{2}{c}{ is more on } \\
government funding & agencies \\
including National & Research \\
Foundation and less on private \\
industries
\end{tabular} & $\begin{array}{lcr}\text { Includes } & \text { internal } & \text { research } \\
\text { funding, government } & \text { funding } \\
\text { through } & \text { National } & \text { Research } \\
\text { Foundation, and industry funding }\end{array}$ \\
\hline 9 & $\begin{array}{l}\text { Internship \& Further } \\
\text { education }\end{array}$ & $\begin{array}{l}\text { Slow decisions through public } \\
\text { sector Governing bodies }\end{array}$ & $\begin{array}{l}\text { Fast decisions through internal } \\
\text { Governing bodies }\end{array}$ \\
\hline 10 & $\begin{array}{lr}\text { Restriction } & \text { on } \\
\text { expansion } & \\
\text { horizontally } & \& \\
\text { vertically } & \end{array}$ & $\begin{array}{l}\text { Depends on financial support and } \\
\text { local traditions }\end{array}$ & $\begin{array}{l}\text { Autonomy for FDI investment } \\
\text { for expansion }\end{array}$ \\
\hline 11 & $\begin{array}{l}\text { Introduction of New } \\
\& \quad \text { Emerging } \\
\text { technologies \& } \\
\text { Models }\end{array}$ & Delayed & Immediate \\
\hline 12 & Curriculum Content & Autonomy to decide curriculum & Autonomy to decide curriculum \\
\hline
\end{tabular}

\section{AUTONOMY FOR STAKEHOLDERS :}

The stakeholders like administrators, teaching and non-teaching faculty members, board of studies responsible of proposing courses and forming curriculum, board of examinations conducting examination and evaluation, and students who want to choose specific elective subjects to get autonomy to innovate the system with responsibility, leads to excellent system. Various levels of autonomy required in universities are discussed below :

\subsection{Autonomy for Collaboration \& Expansion:}

Universities can enhance their network infrastructure by means of collaboration with industries, alumni, and other educational and research institutions. Universities can also expand their services at 
national and international level by offering their courses in collaboration with other universities or HEIs. Thus autonomy can be used by the universities to encash the opportunity of both collaborations and expanding their services for enhanced admission. The universities have the opportunity to use their autonomy for collaboration and expansion at national and international level.

\section{(1) At national/local level :}

Using the autonomy, the universities can collaborate for both academic training and research facility sharing. Based on teamwork and resource sharing, researchers can utilize the scarcely available research facilities so that the country can avoid repetition of and underutilization of costly equipment. Universities can specialize in certain areas and provide super-specialty courses in such areas instead of providing all courses in all possible areas. This also allows optimum utilization of qualified faculty by the universities in a given specialized subject.

\section{(2) At international /Global level :}

Global collaboration between many universities through sufficient autonomy can give many opportunities to share the ideas, pedagogy used for effective teaching and learning processes, offer shared courses, dual degree programmes, cultural exchange programmes, research collaborations between different countries, etc. International collaborations at academic teaching -learning level, as well as at research and employment level have many constraints and implications in higher education.

\subsection{Autonomy for Innovation :}

Innovation is defined as finding alternative application for a product or a service or a process. Innovation can be also defined as doing a new way of doing things with the intention to decrease the utilization of resources. Universities should have the autonomy to make decisions related to their academic activities, research activities, and evaluation of students for offering degrees to achieve excellence. Further, using autonomy, the universities can innovate their physical infrastructure, digital infrastructure, academic teaching-learning infrastructure, intellectual property infrastructure, emotional infrastructure, and networked infrastructure [29].

\section{(1) Academic Autonomy :}

Universities should utilize their autonomy as an opportunity to innovate their academic affairs including offering new courses in existing departments and by starting new departments in different subject areas. They should also use their autonomy to update the curriculum as per industry standards by involving industry people on the board of studies. The university should see that new and innovative pedagogy is implemented to make the teaching-learning process effective using all possible resources including innovative technology. Academic autonomy should be extended to provide additional employability skills in a given area by utilizing experts from the industry and society.

\section{(2) Research Autonomy :}

Universities should also utilize their autonomy for innovations in research contributions through innovative practices of promoting research. This include resource mobilization, motivating and target setting to the faculty members, creating research opportunity for students at UG and PG levels, offering research projects to every faculty members, creating opportunity for scholarly publications through university publishing press, enhancing the number of scholarship offers to the researchers in identified areas of research, seeking public sector and private sector funding to promote research, creating centre for excellence in identified areas and offering additional support, collaborating with other institutions both at national level and international level, etc. In this direction, recently many new research frameworks are proposed [36] to involve UG and PG students in compulsory research models which include industry analysis [37], company analysis [2], [38], patent analysis [3], etc. University should also use its autonomy for encouraging the faculty and other researchers for enhanced research contributions and scholarly publications by offering additional incentives by fixing targets and accountability [39-41].

\section{(3) Evaluation Autonomy :}

Universities should also use their autonomy to improve their evaluation system as a continuous evaluation system with components like competency based assessment in choice based credit system [42-45]. Evaluation of competency of students in doing a particular job can be criteria for offering a degree. Such competency based evaluation system, even though considered as innovative and industry 
specific, the modality of such evaluation system to be acceptable from the society is yet to be developed.

\subsection{Autonomy for using Technology :}

Technology is defined as an application of science to solve a problem in industry or society. Use of innovative technology in Universities helps them to progress in their objectives of providing quality higher education to the aspirants. As mentioned in the previous section, adopting suitable Technology also helps in effective collection of information for research and analysis. Identifying suitable technologies for teaching, learning, administration, and research by providing office automation, learning management system, administrative automation, online digital library, online examination and evaluation system are essential. Technology adoption can be broadly divided into two categories as (1) use of technology for university functions including teaching - learning \& research, and (2) promotion of advances in technology for its progress to solve problems in society.

\section{(1) Use of technology for automation of university administration :}

This includes the use of technology for automating its marketing and promotion, its activity and courses, admission process, administration, fees collection and payroll management. Systematically developed education ERP software are available for procurement and can be customized for integrating various functions of the university administration.

\section{(2) Teaching Emerging Technology in Curriculum :}

Universities should use their autonomy to focus on teaching introduction to emerging technologies as a common subject to all courses at UG level and detailed teaching of individual emerging technologies as super specialty subjects in both UG and PG courses. Autonomy should be used by the universities to start Bachelor and Masters degree programmes in emerging technologies and expected breakthrough technologies [46] in the School of Engineering \& Technology. Since technology has the potential to solve almost all problems of the people of society, it has to be given priority in designing curriculum. The emerging technologies under Universal technologies [47], [48] like : (1) ICCT underlying technologies and (2) Nano underlying technologies are suggested to be used in the university curriculum.

\section{(3) Using Technology for Teaching-Learning Process :}

Education technologies are useful in making teaching -learning processes effective and efficient in offering higher education services. These technologies used in campus based universities include audio technologies, video technologies, software and hardware technologies, simulation technologies, various design technologies, and information communication and computation technologies (ICCT) including the internet for information retrieval, etc. Technological tools used for teaching-learning processes helps the faculties to share information with all the students equally and hence supports to maintain a better quality of teaching-learning processes thereby the university gets better bonding with the students. The campus based universities should use their autonomy to identify and use suitable technology tools to customize the higher education for individuals thereby differentiate themselves compared to online and MOOC based universities [49].

\section{(4) Promoting Technology through $R$ \& D :}

Research focussed universities also have a responsibility to develop technology and transfer it suitably to the industries for healthy industrial and social development. In this regard, Campus based universities, by using their autonomy, can initiate collaborative research for development and transfer of technology to industries [50-52].

\section{CONSEQUENCES OF AUTONOMY FOR UNIVERSITIES :}

The autonomy given to the university or autonomy taken by the university has many consequences for its stakeholders. The consequences of utilizing autonomy are different for public universities and private universities.

6.1 Public Universities : Since Public universities have born with social justice objectives and funded by local government, giving autonomy to them may lead to misuse of power and consequently end to favourism and corruption. The shortage of funds and other resources, inability of making quick decisions due to hectic procedures involved, many local and political reasons, absence of role models, 
weak accountability, and many times due to the inability of leaders, public universities fail to utilize autonomy given to them. Such constraints lead to non-utilization of autonomy for constructive works. Many times, the leaders of public universities use Black ocean strategy [4] for their survivalinstead of contributing to society through developing an innovative and excellent university.

6.2 Private Universities : Contrary to public universities, private universities take autonomy and utilize it effectively both for horizontal expansion and vertical expansion using White ocean strategy [8]. Since they use their autonomy for growth through innovative manner, they need less time in each stage of their growth life-cycle to reach excellence. Private universities take more risk to accumulate resources and utilize them for the development of Physical infrastructure, Digital infrastructure, Academic teaching-learning infrastructure, IPR infrastructure, Emotional infrastructure, and Networked infrastructure effectively and efficiently using their autonomy [29]. Hence they have a better potential for accelerated growth by consuming less time. It is observed that private universities follow all components of Theory of Accountability [53], in their academic and research performance [54], [55], they have a better chance to reach world class level in comparatively less time. Table 5 gives support for this argument that private universities, using their autonomy effectively can perform better and reach excellence compare to public universities.

\section{CONCLUSION :}

By considering the fact that the campus based universities offering higher education with autonomy in their operations, it is argued that such universities have opportunities to innovate and substantially improve the overall quality of education. The decision on using autonomy to innovate university operations gives an opportunity to show their existence globally. It is found that such efforts are essential for existence due to enhanced challenges through online courses and online universities. Hence many campus based universities are redefining their quality and teaching-learning model using various generic strategies which include either survival strategy, or sustainability strategy, or differentiation strategy, or monopoly strategy, or growth \& prosper strategy depending on their present status and future plans. The challenges and opportunities of present generation campus based universities and how such challenges can be addressed using their operational autonomy to aim for excellence are identified from different stakeholders point of view. A review on university performance \& ranking of USA universities is done and commented by assuming private universities have more autonomy compared to public universities to innovate in their operations. A detailed analysis is carried out to know the nature and usage of autonomy to be given to the universities for academic, research, and technology based innovations, and autonomy for collaboration and expansion are discussed using trend analysis by considering the challenges of autonomy for the stakeholders, and finally the predicted consequences of utilizing autonomy for public universities and private universities discussed.

\section{REFERENCES :}

[1] Shubhrajyotsna Aithal \& Aithal, P. S. (2019). How to Customize Higher Education at UG \& PG levels using Patent Analysis \& Company Analysis as New Research Methods in Technology, In Information Technology and Education, Challenges and Opportunities of Smarter Learning Systems, New Delhi Publishers, India. Chapter 3, pp. 25-59. ISBN: 978-93-88879-13-2.

[2] Aithal, P. S. (2017). Company Analysis - The Beginning Step for Scholarly Research. International Journal of Case Studies in Business, IT and Education (IJCSBE), 1(1), 1-18. DOI: http://dx.doi.org/10.5281/zenodo.573769.

[3] Aithal, P. S. \& Shubhrajyotsna Aithal (2018). Patent Analysis as a New Scholarly Research Method. International Journal of Case Studies in Business, IT, and Education (IJCSBE), 2(2), 33-47. DOI: http://dx.doi.org/10.5281/zenodo.1404184.

[4] Aithal, P. S., Suresh Kumar, P. M. (2015). Black Ocean Strategy - A Probe into a New type of Strategy used for Organizational Success. GE International Journal of Management Research, 3(8), 45 - 65. DOI : http://doi.org/10.5281/zenodo.163423. 
[5] Hou, Shengtian (2007). Green ocean strategy: Obtaining sustainable competitive advantage, Beijing: Tsinghua University Press, pp. 183-197.

[6] Porter, M. E. (1997). Competitive strategy. Measuring Business Excellence, 1(2), 12-17.

[7] Kim, W. C., \& Mauborgne, R. (2005). Blue ocean strategy. California Management Review, 47(3), 105-121.

[8] Aithal, P. S. (2016). The concept of Ideal Strategy \& its realization using White Ocean Mixed Strategy. International Journal of Management Sciences and Business Research (IJMSBR), 5(4), 171-179. DOI : http://doi.org/10.5281/zenodo.161108.

[9] Volkwein, J. F. (1986). Campus autonomy and its relationship to measures of university quality. The Journal of Higher Education, 57(5), 510-528.

[10] McCulloch, M. (1993). Total quality management: its relevance for higher education. Quality assurance in education, 1(2), 5-11.

[11] Van Vught, F. A. \& Westerheijden, D. F. (1994). Towards a general model of quality assessment in higher education. Higher Education, 28(3), 355-371.

[12] Kwiatkowski, S. (1990). Survival through excellence: Prospects for the Polish university. European Journal of Education, 391-398.

[13] Avdjieva, M., \& Wilson, M. (2002). Exploring the development of quality in higher education. Managing Service Quality: An International Journal, 12(6), 372-383.

[14] Milliken, J., \& Colohan, G. (2004). Quality or control? Management in higher education. Journal of Higher Education Policy and Management, 26(3), 381-391.

[15] Henkel, M. (2005). Academic identity and autonomy in a changing policy environment. Higher education, 49(1-2), 155-176.

[16] Bridges, D. (2006). The practice of higher education: in pursuit of excellence and of equity. Educational Theory, 56(4), 371-386.

[17] Bladh, A. (2007). Institutional autonomy with increasing dependency on outside actors. Higher Education Policy, 20(3), 243-259.

[18] Simons, M., \& Elen, J. (2007). The 'research-teaching nexus' and 'education through research': An exploration of ambivalences. Studies in higher education, 32(5), 617-631.

[19] Kallison, J. M. \& Cohen, P. (2010). A new compact for higher education: Funding and autonomy for reform and accountability. Innovative Higher Education, 35(1), 37-49.

[20] Bleiklie, I. (2011). Excellence, quality and the diversity of higher education systems. In Questioning excellence in higher education (pp. 21-35). Brill Sense.

[21] Zhang, J. (2014). Developing excellence: Chinese university reform in three steps. Nature News, 514(7522), 295.

[22] Erkkilä, T. \& Piironen, O. (2014). Shifting fundaments of European higher education governance: Competition, ranking, autonomy and accountability. Comparative Education, 50(2), 177-191.

[23] O'Neill, O. (2015). Integrity and quality in universities: Accountability, excellence and success. Humanities, 4(1), 109-117.

[24] Aithal, P. S., \& Kumar, P. M. (2016). Innovations in private universities: a case of Srinivas university. International Journal of Management, IT and Engineering, 6(1), 250-264. DOI : http://doi.org/10.5281/zenodo.161151.

[25] Sankaran, K. \& Joshi, G. V. (2016). Autonomy for Excellence in Higher Education in India. Nitte Management Review, 10(2), DOI: http://doi.org/10.17493/nmr/2016/118217. 
[26] Tasopoulou, K., \& Tsiotras, G. (2017). Benchmarking towards excellence in higher education. Benchmarking: An International Journal, 24(3), 617-634.

[27] Michavila, F. \& Martinez, J. M. (2018). Excellence of universities versus autonomy, funding and accountability. European Review, 26(S1), S48-S56.

[28] Parker, A. \& Tritter, J. (2006). Focus group method and methodology: current practice and recent debate. International Journal of Research \& Method in Education, 29(1), 23-37.

[29] Aithal, P. S. \& Shubhrajyotsna Aithal (2019). Building World-Class Universities : Some Insights \& Predictions. International Journal of Management, Technology, and Social Sciences (IJMTS), 4(2), 13-35. DOI: http://doi.org/10.5281/zenodo.3377097.

[30] Aithal, P. S. \& Aithal, Shubhrajyotsna (2019). Innovation in B.Tech. Curriculum as B.Tech. (Hons) by integrating STEAM, ESEP \& IPR features. International Journal of Case Studies in Business, IT, and Education (IJCSBE), 3(1), 56-71. DOI: http://doi.org/10.5281/zenodo.3248630.

[31] Sife, A., Lwoga, E., \& Sanga, C. (2007). New technologies for teaching and learning: Challenges for higher learning institutions in developing countries. International journal of education and development using ICT, 3(2), 57-67.

[32] Aithal, P. S., \& Kumar, P. M. (2016). Opportunities and Challenges for Private Universities in India. International Journal of Management, IT and Engineering, 6(1), 88-113. DOI : http://doi.org/10.5281/zenodo.161157.

[33] Aithal, P. S. \& Suresh Kumar P. M. (2018). Approaches to Confidence Building as a Primary Objective in Postgraduate Degree Programmes. International Journal of Applied Engineering and Management Letters (IJAEML), 2(1), 64-71. DOI: http://dx.doi.org/10.5281/zenodo.1205185.

[34] Salmi, J. (2001). Tertiary education in the 21st century: challenges and opportunities. Higher Education Management, 13(2), 105-130.

[35] Aithal, P. S. \& Aithal, Shubhrajyotsna (2019). Analysis of Higher Education in Indian National Education Policy Proposal 2019 and its Implementation Challenges. International Journal of Applied Engineering and Management Letters (IJAEML), 3(2), 1-35. DOI: http://doi.org/10.5281/Zenodo.3271330.

[36] Aithal, P. S. \& Aithal, Shubhrajyotsna (2019). New Directions in Scholarly Research- Some Fearless Innovations \& Predictions for 21st Century Research. International Journal of Management, Technology, and Social Sciences (IJMTS), 4(1), 1-19. DOI: https://doi.org/10.5281/zenodo.2557222.

[37] Aithal, P. S. (2017). Industry Analysis - The First Step in Business Management Scholarly Research. International Journal of Case Studies in Business, IT and Education (IJCSBE), 2(1), 1-13. DOI: http://dx.doi.org/10.5281/zenodo.810347.

[38] Aithal, P. S. (2017). An Effective Method of Developing Business Case Studies based on Company Analysis, International Journal of Engineering Research and Modern Education (IJERME), 2(1), 16-27. DOI: http://dx.doi.org/10.5281/ZENODO.400579.

[39] Aithal, P. S. (2018). How to Boost Faculty Research Performance in HEI's to Improve Intellectual Property by Integrating it with Faculty Compensation - A "Theory of Accountability" based Framework. International Journal of Management, Technology, and Social Sciences (IJMTS), 3(2), 130-151. DOI: https://doi.org/10.5281/zenodo.1689055.

[40] Aithal, P. S. \& Suresh Kumar, P. M. (2017). Challenges and Opportunities for Research \& Publications in Higher Education. International Journal of Scientific Research and Modern Education (IJSRME), 2(1), 42-49. DOI: http://dx.doi.org/10.5281/ZENODO.400619.

[41] Aithal, P. S. \& Suresh Kumar, P.M. (2016). ABC Model of Research Productivity and Higher 
Educational Institutional Ranking. International Journal of Education and Management Engineering (IJEME), 6(6), 74-84. DOI: http://doi.org/10.5281/zenodo.161160.

[42] Aithal, P. S. \& Suresh Kumar, P. M. (2016). Student Evaluation and Reforms in Higher Education Institutions, International Journal of Multidisciplinary Research and Modern Education (IJMRME), 2(1), 652-661, DOI : http://doi.org/10.5281/zenodo.160932.

[43] Aithal, P. S. \& Suresh Kumar, P.M. (2016). Analysis of Choice Based Credit System in Higher Education. International Journal of Engineering Research and Modern Education (IJERME), 1(1), 278-284. DOI: http://doi.org/10.5281/zenodo.161046.

[44] Chyung, S. Y., Stepich, D., \& Cox, D. (2006). Building a competency-based curriculum architecture to educate 21st-century business practitioners. Journal of Education for Business, 81(6), 307-314.

[45] Chacko, T. V. (2014). Moving toward competency-based education: Challenges and the way forward. Archives of Medicine and Health Sciences, 2(2), 247.

[46] Aithal, P. S. \& Shubhrajyotsna Aithal (2015). A review on Anticipated Breakthrough Technologies of 21st Century. International Journal of Research \& Development in Technology and Management Sciences, 21(6), 112 - 133. DOI: http://doi.org/10.5281/zenodo.61617.

[47] Aithal, P. S. and Shubhrajyotsna Aithal (2018). Study of various General-Purpose Technologies and their contribution towards developing Sustainable Society. International Journal of Management, Technology, and Social Sciences (IJMTS), 3(2), 16-33. DOI: http://dx.doi.org/10.5281/Zenodo.1409476.

[48] Aithal, P. S. \& Shubhrajyotsna Aithal (2015). Ideal Technology Concept \& its Realization Opportunity using Nanotechnology, International Journal of Application or Innovation in Engineering \& Management (IJAIEM), 4(2), 153 - $164 . \quad$ DOI: http://doi.org/10.5281/zenodo.61591.

[49] Blau, I., Peled, Y., \& Nusan, A. (2016). Technological, pedagogical and content knowledge in one-to-one classroom: teachers developing "digital wisdom”. Interactive Learning Environments, 24(6), 1215-1230.

[50] Ankrah, S., \& Omar, A. T. (2015). Universities-industry collaboration: A systematic review. Scandinavian Journal of Management, 31(3), 387-408.

[51] Aithal, P. S. and Shubrajyotsna Aithal (2016). Nanotechnology Innovations and Commercialization - Opportunities, Challenges \& Reasons for Delay. International Journal of $\begin{array}{llll}\text { Engineering and } \quad \text { Manufacturing (IJEM), 6(6), } & \text { 15-25. }\end{array}$ http://doi.org/10.5815/ijem.2016.06.02.

[52] Aithal, P. S. \& Shubhrajyotsna Aithal (2016). A New Model for Commercialization of Nanotechnology Products and Services. International Journal of Computational Research and Development, 1(1), 84-93. DOI : http://doi.org/10.5281/zenodo.163536.

[53] Aithal, P. S. \& Suresh Kumar, P. M. (2016). Theory A for Optimizing Human Productivity.IRAInternational Journal of Management \& Social Sciences, 4(3), 526-535. DOI : http://doi.org/10.21013/jmss.v4.n3.p2.

[54] Aithal, P. S. and Suresh Kumar, P. M. (2016). Organizational Behaviour in $21^{\text {st }}$ Century Theory A for Managing People for Performance. IOSR Journal of Business and Management (IOSR-JBM), 18(7), 126-134. DOI: http://doi.org/10.9790/487X-180704126134.

[55] Aithal, P. S. \& Suresh Kumar P. M. (2017). Interconnecting Theory A and ABC Model of Organizational Performance. International Journal of Management, Technology and Social Sciences (IJMTS), 1(1), 1-13. DOI: http://dx.doi.org/10.5281/zenodo.268598. 